\title{
Respiration of the Black Sea Turbot (Scophthalmus maeoticus) Eggs as an Indicator of its Development
}

\author{
Antonina N. Khanaychenko*, Leonid S. Svetlichny, \\ Vitaly E. Giragosov and Elena S. Hubareva \\ Kovalevsky Institute of Marine Biological Research RAS \\ 2 Nakhimov, Sevastopol, 299011, Russia
}

Received 19.12.2016, received in revised form 23.01.2017, accepted 28.02.2017

Rate of oxygen consumption of the Black Sea turbot (Scophthalmus maeoticus) during early ontogenesis depending on stage of development, morphological norm and temperature (11 and $\left.16^{\circ} \mathrm{C}\right)$ was studied. Oxygen consumption at blastula stage was the lowest, varied between 0.0057 and $0.0061 \mathrm{mg} \mathrm{O}_{2}$ ind $^{-1} \mathrm{~h}^{-1}$ and was independent among egg batches in studied temperature range. Aerobic metabolism increased 22 times at $16^{\circ} \mathrm{C}$, reaching $0.1348 \pm 0.0205 \mathrm{mg} \mathrm{O} \mathrm{O}_{2} \mathrm{ind}^{-1} \mathrm{~h}^{-1}$, and only 13 times at $11{ }^{\circ} \mathrm{C}$ from blastula to active embryo stage. Temperature interval $5{ }^{\circ} \mathrm{C}$ gave a mean $Q 10$ of 2.6 for the rate of oxygen consumption of the Black Sea turbot during embryogenesis. Aerobic metabolism appeared twice lower at gastrula stage in embryos with morphological defects revealed from tail bud stage onwards incompatible with the development to a viable larvae, than that in normally developing embryos.

Keywords: Black Sea turbot, Scophthalmus maeoticus, respiration of the eggs, development.

Citation: Khanaychenko A.N., Svetlichny L.S., Giragosov V.E., Hubareva E.S. Respiration of the Black Sea turbot (Scophthalmus maeoticus) eggs as an indicator of its development. J. Sib. Fed. Univ. Biol., 2017, 10(1), 9-19. DOI: 10.17516/19971389-0004.

(C) Siberian Federal University. All rights reserved

* Corresponding author E-mail address: a.khanaychenko@gmail.com 


\title{
Дыхание икры черноморского калкана \\ (Scophthalmus maeoticus) как показатель ее развития
}

\author{
А.Н. Ханайченко, Л.С. Светличный, \\ В.Е. Гирагосов, Е.С. Губарева \\ Институт морских биологических исследований \\ имени А.О. Ковалевского РАН \\ Россия, 299011, Севастополь, пр. Нахимова, 2
}

Исследовано дыхание черноморского калкана (Scophthalmus maeoticus) в течение раннего онтогенеза в зависимости от стадии, наличия морфологических аномалий развития и температуры (11 и $\left.16{ }^{\circ} \mathrm{C}\right)$. Скорость потребления кислорода была наименьшей на стадии

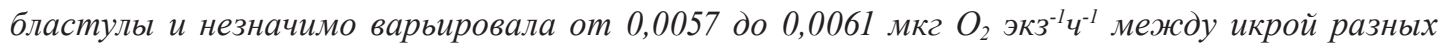
серий и при разных температурах. При нормальном морфологическом развитии аэробный метаболизм возрастает от бластуль до стадии подвижного эмбриона в 22 раза, равняясь

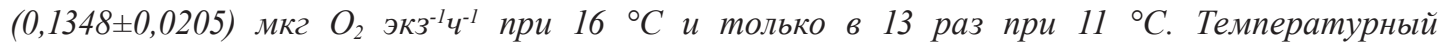
коэффициент Q10 составил в среднем 2,6 для аэробного метаболизма калкана в течение эмбриогенеза. Аэробный метаболизм на стадии гаструль оказался вдвое ниже у икры, для которой на более поздних стадиях, начиная с образования хвостовой почки, обнаруживали аномалии развития, не совместимые с развитием до жизнеспособной личинки, по сравнению с нормально развивавщейся икрой.

Ключевые слова: черноморский калкан, Scophthalmus таеотісиs, дыхание икры, развитие.

\section{Введение}

Черноморская камбала калкан Scophthalmus maeoticus (Pallas) (Froese, Pauly, 2016) является одним из ценных промысловых видов рыб Черного моря и перспективным объектом марикультуры. Калкан подвергался значительному перелову на протяжении десятилетий в результате тралового лова с 1950-х гг. В Севастопольском регионе с 2009 по 2014 г. относительные уловы калкана снизились более чем десятикратно, а численность оплодотворенной икры калкана в ихтиопланктонных ловах упала практически до нуля (Гирагосов и др., 2015). Принимаемые в настоящее время меры по регулированию промысла не могут гарантировать быстрого восстановления стабильного естественного воспроизводства и роста промыслового запаса калкана. Поэтому одновременно с разработкой научно обоснованных методов эксплуатации естественной популяции калкана необходимо способствовать становлению его искусственного воспроизводства.

Наличие высококачественных икры и личинок - одно из важнейших условий для эффективного воспроизводства вида. Плодовитость калкана очень высокая, самки потенциально могут выметать порционно за нерестовый сезон 2-12 млн икринок. Но выживаемость икры и личинок на ранних стадиях развития как в море, так и в условиях аквакультуры невысока из-за их чувствительности к большому числу негативных внутренних и внешних факторов. В море у бе- 
регов Севастополя калкан выметывает икру на глубине от 30 до 100 м (преимущественно на 50 м) при температуре придонного слоя 6-10 ${ }^{\circ} \mathrm{C}$ с середины апреля до начала июня. Оплодотворенная пелагическая икра поднимается к поверхности, где развивается в хорошо аэрируемом слое при температуре от 10 до $18{ }^{\circ} \mathrm{C}$. Эмбрионы калкана не способны избегать резких смен температуры, которые происходят в период весенних штормов, поэтому температурный фактор играет важную роль во время раннего онтогенеза калкана и влияет на выживаемость. Норма морфогенетических характеристик на каждом этапе эмбриогенеза определяет жизнеспособность личинок после выклева и их эффективный переход на внешнее питание и, как следствие, обеспечивает высокую выживаемость генерации (Kjorsvik et al., 2003).

Метаболизм черноморского калкана на стадиях от икры до малькового периода изучен отрывочно, без связи с морфологическими изменениями организма (Столбов и др., 1995; Минкина и др., 2006). Закономерности изменения потребления кислорода калканом на разных этапах эмбрионального и раннего постэмбрионального развития в зависимости от нормальности развития и температурного фактора до настоящего времени практически не изучены. Данное исследование было направлено на определение закономерностей изменения потребления кислорода калканом на разных этапах эмбрионального и раннеличиночного развития в диапазоне температур жизнедеятельности для оценки уровня обмена нормально и аномально развивающихся организмов.

\section{Материалы и методы}

В экспериментах было использовано три партии оплодотворенной икры, каждая из которых была получена путем сцеживания по- ловых продуктов от одной пары производителей калкана, отловленных жаберными сетями в районе нереста. Производителей доставляли в лабораторию и после предварительной оценки исходного качества икры и спермы осуществляли искусственное оплодотворение икры при температуре $(11 \pm 0,5){ }^{\circ} \mathrm{C}$. Оплодотворение и развитие икры оценивали по общепринятым методикам (Kjorsvik et al., 2004) на стадии 8 бластомеров в трех пробах по 100 икринок. Нормально развивающаяся икра имеет положительную плавучесть, прозрачная, с небольшим объемом перивителлинового пространства, бластомеры при делении имеют правильную форму, икринки находятся на одной стадии. После оценки качества икру промывали дезинфицированной морской водой (18\%), сохраняли в термостатированных сосудах при температуре $(11 \pm 0,5){ }^{\circ} \mathrm{C}$ и в дальнейшем использовали в экспериментах для определения скорости потребления кислорода.

Измерение дыхания икры проводили при двух температурных режимах -11 и $16^{\circ} \mathrm{C}$ (во второй экспериментальной серии нижний температурный режим постепенно повышали, начиная со стадии органогенеза таким образом, что лецитотрофные личинки находились в режиме $12{ }^{\circ} \mathrm{C}$ ). Диапазон экспериментальных температур соответствовал средним колебаниям температуры поверхности моря в период массового развития икры калкана и физиологическим лимитам температур для раннего развития калкана (Битюкова и др., 1984). В процессе экспериментальных исследований дыхания калкана ежедневно проводили визуальные наблюдения за развитием эмбрионов и лецитотрофных личинок, определяя последовательность этапов и наличие или отсутствие аномалий развития по морфологическим критериям. Развитие эмбрионов оценивали на стадиях дробления, бластулы, 
гаструлы, органогенеза, роста хвостового отдела и стадии подвижного эмбриона, личинок - на выклеве и перед началом активного питания (Дехник, 1973). Для этого аликвоты икры и личинок предварительно просматривали под бинокуляром МБС-2 при увеличении $8 \times 4$, а затем производили прижизненную цифровую съемку объектов с помощью инвертированного светового микроскопа Nikon Eclipse (при увеличении $\times 4 ; \times 10 ; \times 20$ ), оснащенного аналоговой видеокамерой, подключенной к компьютеру. Прозрачность икры калкана позволяла с помощью микроскопа легко оценить характер деления бластомеров на стадии дробления и морфологию эмбриона на дальнейших этапах развития.

Скорость дыхания ( $\mathrm{R}$, мкг $\mathrm{O}_{2}$ экз ${ }^{-1} \mathrm{u}^{-1}$ ) определяли методом закрытых респирометров, в качестве которых были использованы шприцы объемом 1-2 мл. В экспериментах использовали фильтрованную и стерилизованную ультрафиолетом морскую воду (ФУМВ) (18%). Предварительно промытые ФУМВ икринки, у которых отсутствовали видимые морфологические признаки патологии, осторожно переносили микропипеткой в наполненные ФУМВ опытные шприцы (в 3-5 повторностях) и помещали в термостаты с постоянной температурой 11 или $16^{\circ} \mathrm{C}$. Исследования дыхания икры проводили в условиях нормоксии; исходная концентрация кислорода при $16{ }^{\circ} \mathrm{C}$ варьировала в пределах 7-8,5 мкг $\mathrm{O}_{2}$ мл$^{-1}$, при $11{ }^{\circ} \mathrm{C}$ - в пределах 7,5-9 мкг $\mathrm{O}_{2}$ мл $^{-1}$. Экспозиция составляла 3-4 ч. В течение инкубации шприцы периодически вращали для перемешивания икринок, устранения возможных застоев воды и уравновешивания концентрации кислорода. Количество потребленного икрой кислорода определяли по разнице его концентрации в контрольных и опытных шприцах в конце экспозиции. Концентрацию кислорода в шприцах вычисляли как среднюю, опреде- ленную по трем порциям воды ( 0,2 мл), вводимым шприцами в измерительную камеру переменного объема, расположенную непосредственно над мембраной люминесцентного датчика кислорода Hach LDO (Svetlichny et al., 2012). Измерения потребления кислорода проводили на последовательных стадиях развития калкана от стадии бластулы до выклева и у лецитотрофных личинок непосредственно после выклева и перед переходом на экзогенное питание. Средние значения скорости потребления кислорода калканом были получены как минимум по пяти измерениям дыхания калкана на разных стадиях развития (30-60 икринок или 2-6 личинок на респирометр). Влияние температуры на потребление кислорода оценивали по $Q 10$, рассчитанным по уравнению Вант Гоффа:

$$
\operatorname{Lg} Q 10=\frac{\left[10\left(\lg V_{2}-\lg V_{1}\right)\right]}{\left(t_{2}-t_{1}\right)},
$$

где $\mathrm{V}_{1}$ - скорость потребления кислорода при температуре $t_{1}$, a $V_{2}$ - скорость потребления кислорода при температуре $\mathrm{t}_{2}$.

Статистическую обработку данных проводили, используя стандартный пакет Excel, оценку достоверности различий средних осуществляли по критерию Стьюдента ( $\mathrm{n}=5$; $\mathrm{p}<0,05)$.

\section{Результаты}

Диаметр оплодотворенной икры калкана составлял $(1,28 \pm 0,03)$ мм, а диаметр жировой капли - $(0,22 \pm 0,01)$ мм, морфологическая норма которых приведена на рис. 1 (1.1-1.7).

В первой экспериментальной серии при температуре $11{ }^{\circ} \mathrm{C}$ были получены сравнительные характеристики дыхания двух разных партий икры от двух разных пар производителей (рис. 2). Оценка, проведенная на стадии 8 бластомеров согласно общеприня- 


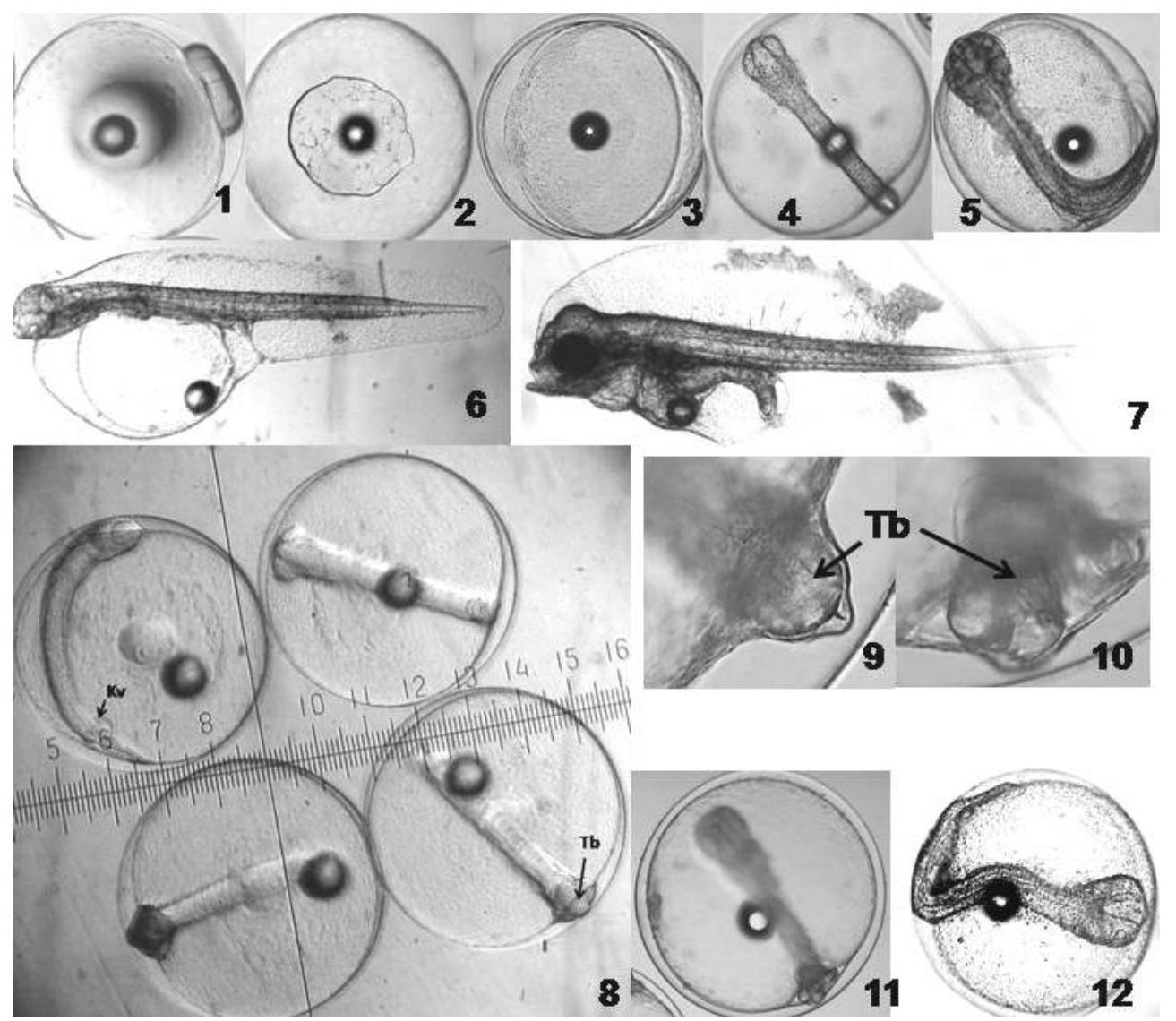

Рис. 1. Развитие калкана в раннем онтогенезе: норма развития 1 - дробление (8 бластомеров); 2 - бластула; 3 - гаструла; 4 - формирование хвостовой почки; 5 - подвижный эмбрион; 6 - личинка на выклеве; 7 - личинка перед началом экзогенного питания; 8 - икра на стадии сегментации; 9 - норма формирования хвостовой почки; 10, 11 - аномалии формирования хвостовой почки; 12 - аномалия хвостового отдела подвижного эмбриона калкана; Kv - Купферов пузырек; Tb - хвостовая почка

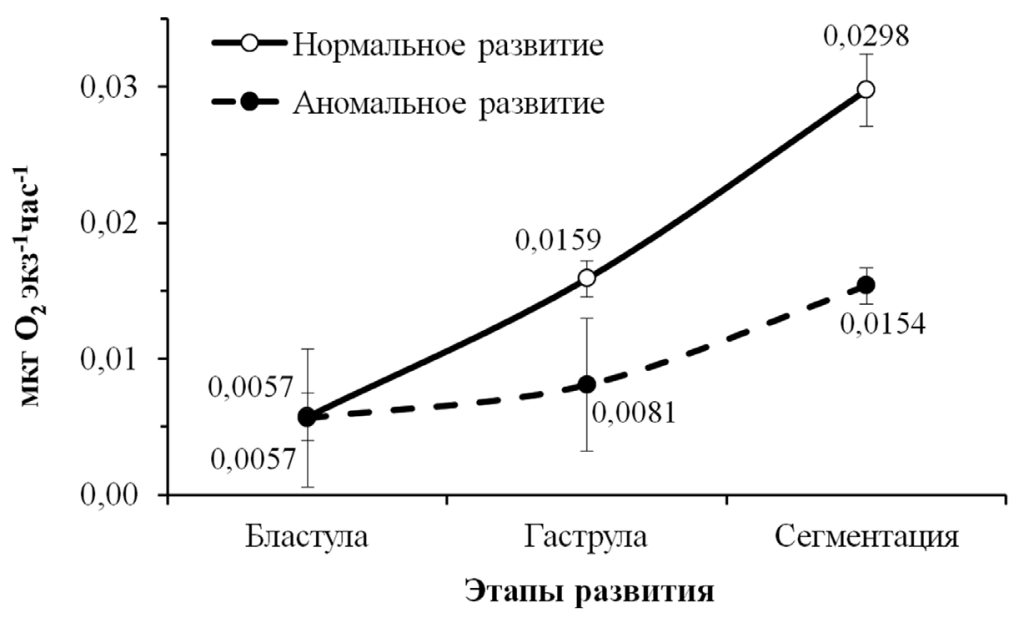

Рис. 2. Потребление кислорода (мкг $\mathrm{O}^{2}$ экз $\left.{ }^{-1} \mathrm{\Psi}^{-1} \pm \mathrm{SD}\right)$ эмбрионами калкана от разных скрещиваний на ранних этапах развития при $11^{\circ} \mathrm{C}$ 
тым методикам (Kjorsvik et al., 2004), показала, что икра развивалась нормально, т.е. происходило синхронное деление бластомеров без признаков аномалий дробления (рис. 1.1); икра была прозрачной и имела положительную плавучесть. Энергетический обмен икры из обеих групп закономерно возрастал в процессе эмбриогенеза от стадии бластулы к стадии органогенеза. На стадии бластулы (рис. 1.2) не было отмечено значимых различий в потреблении кислорода икрой из обеих партий: $(0,0057 \pm 0,0018)$ и $(0,0057 \pm 0,0005)$ мкг $\mathrm{O}_{2}$ экз $^{-1}$ ч$^{-1}$. Однако скорость дыхания на стадии гаструлы (рис. 1.3) $(\mathrm{p}<0,005)$ и на стадии сегментации $(\mathrm{p}<0,005)$ оказалась достоверно вдвое ниже у эмбрионов, в развитии которых морфологические аномалии определялись на более поздних стадиях, от начала появления Купферова пузырька (рис. 1.8), при формировании хвостовой почки (рис. 1.10-1.11) и роста хвостового отдела (рис. 1.12), по сравнению с эмбрионами, у которых не было обнаружено патологии формирования хвостовой почки (рис. 1.9) и в дальнейшем хвостового отдела. Выклев из партии икры с более низким кислородным обменом был более длительным и составил не более 2 \% личинок, из которых более 90 \% обнаруживали аномалии развития хвостовой части. Выклев личинок из партии с более высоким кислородным обменом при $11^{\circ} \mathrm{C}$ был тоже растянут во времени и не превышал 10 \%, но доля разнообразных аномалий развития составила менее $30 \%$.

Во второй экспериментальной серии оценивали кислородный обмен эмбрионов одной партии икры (полученной от одной пары производителей) при двух температурных режимах (11 и $\left.16{ }^{\circ} \mathrm{C}\right)$. Скорость метаболизма калкана закономерно возрастала по мере развития зародыша, достигая максимальной величины на стадии подвижного эмбриона (рис. 1.5) перед выклевом вне зависимости от температурного режима, однако уровень метаболизма эмбрионов значимо увеличивался с повышением температуры (рис. 3). В начале эмбриогенеза (от ранней до поздней бластулы) потребление кислорода икрой калкана было низким и практически не зависело от температурного режима, различия были незначимыми (p>0,05): $(0,0059 \pm 0,0025)$ мкг $\mathrm{O}_{2}$ эк $3^{-1} \mathrm{ч}^{-1}$ при $11{ }^{\circ} \mathrm{C}$ и $(0,0061 \pm 0,0016)$ мкг $\mathrm{O}_{2}$ экз ${ }^{-1} ч^{-1}$ при $16{ }^{\circ} \mathrm{C}$ (рис. 3). Потребление кислорода эмбрионами калкана повышалось к середине эмбриогенеза, но значимо быстрее при более высокой температуре, чем при низкой: на стадии гаструлы $(\mathrm{p}<0,05)-(0,0161 \pm 0,0028)$ мкг $\mathrm{O}_{2}$ эк $^{-1}$ ч$^{-1}$ при $16{ }^{\circ} \mathrm{C}$ и $(0,0081 \pm 0,0005)$ мкг $\mathrm{O}_{2}$ экз $^{-1}$ ч$^{-1}$ при $11{ }^{\circ} \mathrm{C}$. В связи с тем что развитие калкана на стадии органогенеза значительно затормаживалось при $11{ }^{\circ} \mathrm{C}$ в первом эксперименте и приводило к низкому проценту выклева даже из нормально развивающейся икры, во втором эксперименте у икры, находящейся в низкотемпературном режиме, на стадии органогенеза температуру повышали на $0,5{ }^{\circ} \mathrm{C}$. На этой стадии кислородный обмен икры также значимо $(\mathrm{t}=0,0008 ; \mathrm{p}<0,05)$ был выше - $(0,0426 \pm 0,0008)$ мкг $\mathrm{O}_{2}$ экз $3^{-1} ч^{-1} п р и$ $16{ }^{\circ} \mathrm{C}$, чем при $11,5{ }^{\circ} \mathrm{C},(0,0278 \pm 0,0045)$ мкг $\mathrm{O}_{2}$ экз $^{-1} \mathbf{4}^{-1}$. Скорость потребления кислорода икрой оказалась максимальна на стадии подвижного эмбриона, в течение которой происходило постоянное активное движение зародыша, подготавливающегося к выклеву, и она также значимо $(\mathrm{t}=0,01 ; \mathrm{p}<0,05)$ различалась при $16^{\circ} \mathrm{C}\left(0,135 \pm 0,0205\right.$ мкг $\mathrm{O}_{2}$ эк $\left.3^{-1} \mathbf{ч}^{-1}\right)$ и $11,5^{\circ} \mathrm{C}$ $\left(0,0801 \pm 0,0115\right.$ мкг $\mathrm{O}_{2}$ эк $\left.3^{-1} \mathrm{ч}^{-1}\right)$. К моменту выклева температуру повышали дополнительно на $0,5{ }^{\circ} \mathrm{C}$; таким образом, на стадии лецитотрофных личинок температура в нижнем диапазоне составляла $12{ }^{\circ} \mathrm{C}$.

Лецитотрофные личинки (рис. 1.6) практически неподвижны, имеют положительную плавучесть за счет желточного мешка и жиро- 


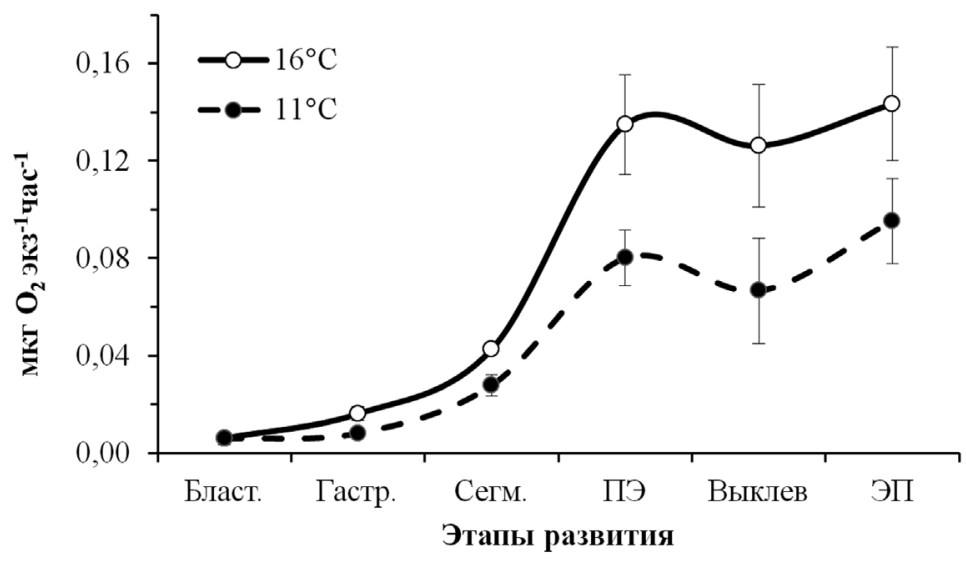

Рис. 3. Потребление кислорода (мкг $\mathrm{O}^{2}$ экз $\left.{ }^{-1} \mathbf{\Psi}^{-1} \pm \mathrm{SD}\right)$ эмбрионами калкана на ранних этапах развития в зависимости от температуры $\left({ }^{\circ} \mathrm{C}\right)$. Бласт. - бластула, Гастр. - гаструла, Сегм. - сегментация, ПЭ подвижный эмбрион, Выклев - личинки после выклева, ЭП - личинки на эндогенном питании перед переходом на экзогенное питание

вой капли под поверхностной пленкой воды, и их обмен в одном и том же температурном режиме не отличался значимо от подвижных эмбрионов (рис. 1.5) перед выклевом (рис. 3). Однако различия дыхания калкана при 12 и $16{ }^{\circ} \mathrm{C}$ оказались значимыми на протяжении всей стадии лецитотрофных личинок (р < $0,05)$. Перед началом экзогенного питания личинок (рис. 1.7) скорость кислородного обмена имела тенденцию к незначительному возрастанию до $(0,0953 \pm 0,0174)$ мкг $\mathrm{O}_{2}$ экз ${ }^{-1} \Psi^{-1}$ при $12{ }^{\circ} \mathrm{C}$ и $(0,1434 \pm 0,0233)$ мкг $\mathrm{O}_{2}$ эк $3^{-1} \Psi^{-1}$ при $16{ }^{\circ} \mathrm{C}$.

Таким образом, скорость потребления кислорода как нормально развивающейся до выклева икры, так и икры, нормально развивавшейся на ранних этапах, но проявляющей на поздних этапах развития отклонения от нормы, не совместимые с жизнеспособностью личинок, незначимо различается на стадии бластулы как в нижнем, так и в верхнем экстремуме диапазона температур жизнедеятельности калкана в раннем онтогенезе. Закономерное возрастание уровня метаболизма в 22 раза наблюдается при развитии нормальных эмбрионов от стадии бластулы к подвиж- ному эмбриону при $16{ }^{\circ} \mathrm{C}$, в то время как при $11{ }^{\circ} \mathrm{C}$ скорость потребления кислорода за тот же период онтогенеза увеличивается только в 13 pa3.

Коэффициент $Q 10$, рассчитанный по нашим данным в изученном диапазоне температур, оказался самым низким $(1,1)$ на стадии бластулы, наиболее высоким $(3,9)$ на стадии гаструлы, 2,6 - на стадии сегментации и 3,2 на стадии подвижного эмбриона, составив в среднем 2,7 для эмбрионального периода.

\section{Обсуждение}

По нашим неопубликованным данным, оплодотворенная икра калкана поднимается от 50-70 до 0 м за 2-2,5 ч и претерпевает перепад температуры от 6-10 ${ }^{\circ} \mathrm{C}$ (в придонном слое воды) до $10-18{ }^{\circ} \mathrm{C}$ (в поверхностном слое воды). Следовательно, икра калкана на стадии бластулы должна быть эволюционно адаптирована как к низким температурам, так и к широкому диапазону температурных изменений. Изученные нами партии икры были получены путем искусственного оплодотворения при $11{ }^{\circ} \mathrm{C}$. Возможно, поэтому на стадии бластулы было получено самое 
низкое значение $Q 10$. Наибольшей термозависимостью характеризуется поздняя стадия гаструлы перед началом органогенеза, что, по-видимому, свидетельствует о том, что именно на этом этапе начинают происходить важные морфогенетические движения в зародыше и скорость этих процессов определяет норму развития.

Полученные данные свидетельствуют о том, что правильное дробление икры (на стадии 8 бластомеров) не всегда является достоверным признаком ее успешного дальнейшего развития и заниженный энергетический метаболизм, начиная со стадии гаструляции, свидетельствует о нарушении гомеостаза икры, который в дальнейшем проявляется в нарушениях развития и приводит к гибели зародыша. После оплодотворения развивающаяся пелагическая икра использует только те вещества, которые были получены ооцитом в процессе оогенеза в яичниках самки. Для обеспечения нормального развития икра должна содержать запас всех веществ, необходимых для поддержания гомеостаза и эмбрионального развития, и метаболические процессы в ней должны происходить с определенной скоростью. Любые нарушения в эмбриогенезе, приводящие к гибели эмбриона или личинки на стадии эндогенного питания, являются результатом нарушения гомеостаза икры. После стадии дробления они, по-видимому, либо являются результатом нарушений трофики ооцитов, либо связаны с нарушениями экспрессии генов зародыша (Cunha et al., 2015).

В икре рыб рода Scophthalmus запасные вещества присутствуют в двух формах и в двух структурах, в желтке и жировой капле. Но жировая капля, на долю которой приходится 55-60 \% от общих липидов, содержащихся в икре (Silversand et al., 1996), находится в неизменной форме в течение всего эмбриональ- ного периода и начинает расходоваться только после выклева личинки. Единственным источником незаменимых питательных веществ, обеспечивающих все метаболические процессы в течение эмбрионального периода, является желток. Фосфолипиды, необходимые для формирования мембран делящихся клеток, тканей и органов зародыша, содержатся только в желтке (Silversand et al., 1996) и составляют 40-45 \% от общих липидов зародыша (Planas et al., 1993). Для нормальной экспрессии генов в процессе развития эмбриона важно определенное содержание и соотношение в липидах желтка незаменимых ненасыщенных жирных кислот (Cunha et al., 2015). Рост и энергетика развития зародыша зависят от эффективного переноса липидных молекул между тканями и клеточными компонентами, особенно в период органогенеза, когда они необходимы для построения достаточного количества дополнительных мембранных структур быстро делящихся клеток и производства энергии для процессов метаболизма и движения зародыша (Cunha et al., 2015).

Вероятнее всего, незначительное «перезревание» икры служит причиной пониженного метаболизма (рис. 2) при аномалиях развития икры, проявляющихся на поздних этапах (рис. 1.11, 1.12). Задержка икры после овуляции в полости яичника приводит к кислородному голоданию икры, которое может вызвать серьезные метаболические изменения (Kjorsvik et al., 2004). В частности, нежелательные окислительные процессы в липидных компонентах, не используемых на этапах дробления и гаструляции, но используемых для формирования тканей и органов зародыша на этапах органогенеза (Silversand et al., 1996).

Даже при нормальных желтковых запасах отклонения от оптимальной для органогенеза температуры, которая в случае камбалы 
калкан, по-видимому, приходится на температуры $\leq 11^{\circ} \mathrm{C}$, может привести к нарушению метаболизма в период от начала сегментации до формирования хвостовой почки, в течение образования и присутствия у эмбриона временной структуры Купферова пузырька. При $11{ }^{\circ} \mathrm{C}$ выявлена достоверная связь между низким кислородным обменом на этапе сегментации, задержкой в развитии, нарушениями (рис. 1.10, 1.11) структуры Купферова пузырька (рис. 1.8), проявляющихся на более поздних этапах развития аномалиями хвостового отдела (рис. 1.12) и, как следствие, низкой выживаемости личинок. Данные по аэробному обмену икры на поздних этапах развития соответствуют полученной ранее закономерности снижения толерантности к пониженным температурам на поздних этапах эмбриогенеза калкана (Битюкова и др., 1984).

При нормальном эмбриональном развитии калкана при $16{ }^{\circ} \mathrm{C}$ характерно более чем 20-кратное повышение уровня обмена и, соответственно, потребности в кислороде, от $(0,0061 \pm 0,0016)$ на стадии бластулы

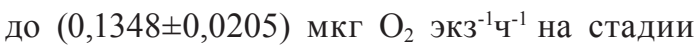
подвижного эмбриона и лецитотрофных личинок. Наши данные согласуются с обобщенными усредненными значениями интенсивности дыхания икры калкана, установленными ранее полярографическим методом (Минкина и др., 2006). Однако данные по скорости потребления кислорода личинками калкана на 1-2-е сутки после выклева, полученные в аппарате Варбурга - 2,39 мкг $\mathrm{O}_{2}$ экз $^{-1}$ ч$^{-1}$ (Столбов и др., 1995), по нашему мнению, являются чрезвычайно завышенными. Найденные нами закономерности изменения потребления кислорода нормально развивающейся икрой калкана в зависимости от температурного режима от стадии бластулы до окончания стадии эндогенного питания аналогичны закономерностям, полученным для атлантического тюрбо (Finn, Ronestad, 2003). Незначительные различия в потреблении кислорода и $Q 10$ могут быть отнесены за счет различий метаболизма организмов с несколько отличающимися размерными и плотностными характеристиками (средний диаметр икры тюрбо - 1,03 мм - меньше диаметра икры калкана, соленосный оптимум развития эмбрионов тюрбо - 34,5 \%о). Увеличение скорости метаболизма в процессе эмбрионального развития зародышей калкана, как и у атлантического тюрбо, по-видимому, связано с возрастанием энергетических трат по мере возрастания интенсивности процессов экспрессии генов, пролиферации и миграции клеток.

\section{Заключение}

Правильное дробление на стадии 8 бластомеров не всегда достоверный признак успешного дальнейшего развития икры калкана. Заниженный уровень обмена на ранних этапах развития может вести к аномалиям, проявляющимся на поздних этапах эмбриогенеза. При температуре $\leq 11^{\circ} \mathrm{C}$ низкий уровень метаболизма приводит к задержке развития во второй половине эмбриогенеза и, как результат, к аномалиям развития, несовместимым с жизнедеятельностью лецитотрофной личинки. Нормальное развитие эмбриона при $16{ }^{\circ} \mathrm{C}$ может быть обеспечено возрастающим потреблением кислорода: от 0,006 на стадии бластулы до $(0,143 \pm 0,023)$ мкг $\mathrm{O}_{2}$ экз $3^{-1} \mathrm{ч}^{-1}$ на стадии подвижного эмбриона. Таким образом, полученные данные позволяют предположить неэффективность раннего нереста калкана в природных условиях до прогрева поверхностных вод как минимум до $12{ }^{\circ} \mathrm{C}$. Наиболее эффективный нерест калкана приходится на период, когда температура поверхностных вод достигает 15-16 ${ }^{\circ} \mathrm{C}$. Наши данные могут иметь практическое значение в аквакультуре 
как для разработки экспресс-метода оценки качества партий икры калкана по уровню ее метаболизма, так и для усовершенствования технологии ее инкубации.

\section{Список литературы}

Битюкова Ю.Е., Ткаченко Н.К., Чепурнов А.В. (1984) Термочувствительность калкана Psetta maeotica (Pallas) (Scophthalmidae) в период эмбрионального развития при искусственном выращивании. Вопросы ихтиологии, 24 (3): 459-463 [Bityukova Y.E., Tkachenko N.K., Chepurnov A.V. (1984) Thermosensitivity of the Black Sea turbot Psetta maeotica (Pallas) (Scophthalmidae) during the period of embryonic development. Journal of Ichthyology [Voprosi Ikhtiologii], 24 (3): 459-463 (in Russian)]

Гирагосов В.Е., Ханайченко А.Н., Рауэн Т.В., Аганесова Л.О., Баяндина Ю.С., Смирнов Д.Ю. (2015) Оценка состояния природной популяции и культивирование черноморской камбалы-калкана в ИнБЮМ (ИМБИ): достижения, ограничения и перспективы. Актуальные проблемы аквакультуры в современный период: материалы международной научной конференции. Ростов-на-Дону, с. $43-46$ [Giragosov V.E., Khanaychenko A.N., Rauen T.V., Aganesova L.O., Baiandina Y.S., Smirnov D.Y. (2015) Assessment of the natural population and cultivation of the Black Sea turbot in IBSS (IMBR): achievements, constraints and perspectives. Current issues in aquaculture: Proceedings of the International Scientific Conference. Rostov-on-Don, p. 43-46 (in Russian)]

Дехник Т.В. (1973) Ихтиопланктон Черного моря. Киев, Наукова думка, 235 с. [Dekhnik T.V. (1973) Ichthyoplankton of the Black Sea. Kyiv, Naukova Dumka, 235 p. (in Russian)]

Минкина Н.И., Павлова Е.В., Самышев Э.З., Гордина А.Д. (2006) Энергетический обмен икры, личинок и мальков черноморской камбалы калкан и его изменения в условиях загрязнения. Системы контроля окружающей среды. Севастополь, НАН Украины. МГИ, с. 347-356 [Minkina N.I., Pavlova E.V., Samyshev E.Z., Gordina A.D. (2006) Energetic metabolism of eggs, larvae and juveniles of the Black Sea turbot and its changes in polluted environment. Systems of environmental control. Sevastopol, NAS Ukraine. MHI, p. 347-356 (in Russian)]

Столбов А.Я., Ставицкая Е.Н., Битюкова Ю.Е., Ткаченко Н.К. (1995) Интенсивность потребления кислорода и экскреция азота у черноморской камбалы калкана Psetta maeotica (Pallas) на разных стадиях личиночного развития. Депонировано в ВИНИТИ, 6 с. [Stolbov A.Ya., Stavitskaya E.N., BityukovaY.E., Tkachenko N.K. (1995) Intensity of oxygen consumption and nitrogen excretion in the Black Sea turbot Psetta maeotica (Pallas) on different stages of development. Deposited in VINITI, 6 p. (in Russian)]

Cunha I., GalanteOliveira S., Rocha E., Urbatzka R., Castro L.F.C. (2015) Expression of intercellular lipid transport and cholesterol metabolism genes in eggs and early larvae stages of turbot, Scophthalmus maximus, a marine aquaculture species. Marine Biology, 162 (8): 1673-1683

Finn R.N., Ronnestad I. (2003) The effect of acute changes in temperature and light on the aerobic metabolism of embryos and yolk-sac larvae of turbot (Scophthalmus maximus). Canadian Journal of Fisheries and Aquatic Sciences, 60: 1324-1331

FroeseR.,PaulyD.Editors.(2016)FishBase.http://www.fishbase.org/photos/ThumbnailsSummary. php?Genus $=$ Scophthalmus $\&$ Species $=$ maeoticus $\#($ accessed on 01/2016)

Kjorsvik E., Hoehne-Reitan K., Reitan, K.I. (2003) Egg and larval quality criteria as predictive measures for juvenile production in turbot (Scophthalmus maximus L.). Aquaculture, 227 (1): 9-20 
Kjorsvik E., Pittman K., Pavlov D. (2004) From fertilisation to the end of metamorphosis functional development. Culture of cold-water marine fish. Moksness E., Kjorsvik E., Olsen Y. (eds.) Oxford, Blackwell Publishing, p. 204-225

Planas M., Labarta U., Fernandez-Reiriz M.J., Ferreiro M.J., Munilla R., Garrido J.L. (1993) Chemical changes during development in turbot (Scophthalmus maximus) eggs and larvae. Physiological and biochemical aspects of fish development. Walther B.T., Fyhn H.J. (eds.) Bergen, Norway, University of Bergen, p. 269-278

Silversand C., Norberg B., Haux C. (1996) Fatty-acid composition of ovulated eggs from wild and cultured turbot (Scophthalmus maximus) in relation to yolk and oil globule lipids. Marine Biology, 125: 269-278

Svetlichny L., Hubareva E., Khanaychenko A. (2012) Calanipeda aquaedulcis and Arctodiaptomus salinus are exceptionally euryhaline osmoconformers: evidence from mortality, oxygen consumption, and mass density patterns. Marine Ecology Progress Series, 470: 15-29 